\title{
O TESTEMUNHO COMO ENSAIO - O ENSAIO COMO TESTEMUNHO: JEAN AMÉRY NOS LIMITES DO INTELECTO ${ }^{1}$
}

\author{
Helmut Paul Erich Galle
}

\section{AUSCHWITZ E O GÊNERO DO ENSAIO}

O ensaio é, conforme definido no verbete de uma enciclopédia dos gêneros literários, "uma forma literária de prosa não ficcional de extensão delimitada na qual um tema de livre escolha é tratado em estilo aberto e com uma linguagem universalmente inteligível" (SCHÄRF, 2009, p. 224). ${ }^{2}$ Outro autor delimita a abrangência temática restringindo-a a um "objeto cultural” [kulturellen Gegenstand] (SCHLAFFER, 2007, p. 522); porém, mesmo excluindo os assuntos das ciências naturais, o campo do ensaio permanece muito amplo. Para Schlaffer (p. 522), o ensaio é "uma forma de prosa na qual um autor comunica sua experiência refletida em estilo livre e compreensível". Se for preciso comprovar a afirmação nos Essais de Michel de Montaigne, autor fundador do gênero, podemos constatar, de fato, a maior amplitude de assuntos que ele submete à sua reflexão vagueante e sutil. Se avisa seus leitores sobre a intenção de fornecer uma descrição fiel de si mesmo, isso inclui os temas mais íntimos e mais remotos, transmitindo sempre um retrato único e pessoal do espírito e do

\footnotetext{
${ }^{1}$ Este artigo está relacionado à pesquisa realizada com uma bolsa da CAPES e do DAAD. z "[...] eine literarische Form der nicht-fiktionalen Prosa von überschaubarer Länge, in der ein frei gewähltes Thema in offenem Stil und allgemein verständlicher Sprache behandelt wird." Todas as traduções do alemão da bibliografia citada e dos ensaios de Améry são nossas.
} 
temperamento do autor. O ensaio é, como o romance no campo da ficção, uma forma aberta que surge na modernidade para atingir uma posição modelar na comunicação escrita sobre o mundo e suas características formais, que são tão indefinidas quanto seus temas: o gênero ensaístico parece quase um sinônimo de ausência de forma e estrutura. Uma definição latino-americana mais recente de Ana Cecilia Olmos (2016, p. 3) também enfatiza o papel constitutivo da experiência pessoal em relação às "condições discursivas do gênero": "a enunciação subjetiva em nome próprio, a liberdade formal, a experiência como única garantia da palavra”.

Considerando a extrema liberdade formal atribuída ao gênero, seria ousado dizer que há um assunto e um estilo de escrita que sejam os mais apropriados para a forma ensaística. Isso, no entanto, é nossa intenção neste artigo. Alegaremos que o holocausto nazista é um assunto que, embora tenha sido tratado em praticamente toda e qualquer forma literária e científica, exige a representação ensaística para sua compreensão mais "completa”. Como exemplo servirão os textos de Jean Améry, em primeiro lugar Jenseits von Schuld und Sühne [Além de culpa e castigo], de 1966, traduzido para o inglês, francês, italiano e russo; e, para o português, sob o título Além do crime e castigo. Tentativas de superação, em 2013. É considerado uma das contribuições mais importantes e originais para a literatura internacional de sobreviventes do holocausto e foi o primeiro texto de impacto, publicado originalmente em alemão.

O ensaio, que evoluiu sobretudo de duas raízes - na França (Montaigne) e na Inglaterra (Bacon) -, não teve a mesma repercussão produtiva na Alemanha, apesar da efêmera apreciação pelos românticos. É no final do século XIX, com Nietzsche, que a forma atinge um nível superior e uma divulgação mais ampla, que resultam, no século XX, também numa conjuntura de reflexões sobre o próprio ensaio, iniciada por Lukács (1911) e retomada, principalmente, por Adorno (1958). Este último enfatiza que o ensaio é "a consequência plena da crítica aplicada ao sistema”, na medida em que consegue falar daquilo que escapa do objetivismo das ciências (ADORNO, 2003a, p. 16). Compartilhando a autonomia com as artes, o ensaio difere delas "por seu meio, conceitos e por sua reivindicação da verdade sem aparência estética” (p. 11). A palavrachave do fundamento epistemológico do ensaio é a experiência e, para Adorno, sua relação com a experiência que, na consciência individual, está sempre inter-relacionada "com a história inteira" (p. 18). Mas o ensaio se recusa tanto à mímesis ficcional quanto à abstração; "a consciência da não 
identidade entre assunto e representação obriga esta [a representação] ao esforço ilimitado", e, nesse aspecto, o ensaio se assemelha à arte literária (ADORNO, 2003a, p. 26). O gênero ensaístico, em seu sentido radical, é negativo e, dessa forma, aproxima-se do ideal da crítica enfatizada por Adorno. Uma reflexão sobre o mundo após Auschwitz, podemos deduzir, deve ser ensaística, ainda mais quando a representação estética do holocausto está vetada por razões morais: transformar em prazer estético o sofrimento das vítimas seria, em última instância, uma reiteração da injustiça (ADORNO, 2003b, p. 424). Segundo Gerhard Scheit (2002, p. 656), editor e comentador do volume respectivo da edição em alemão que reúne as obras de Améry, o livro Jenseits von Schuld und Sühne [Além de culpa e castigo] pode "diretamente valer como paradigma desse gênero específico da escrita [...]", porque o autor "coloca em evidência, de todos os lados, os limites do pensamento identitário - sem ao mesmo tempo simplesmente rejeitá-lo". ${ }^{3}$

De fato, o filósofo teve conhecimento imediato do ensaio sobre "A tortura" quando este saiu na revista Merkur em junho de 1965 (SCHEIT, 2002, p. 673) e elogiou o texto na sua preleção sobre "A metafísica" (ADORNO, 1998, p. 166): o autor expressaria "de maneira diretamente admirável as mudanças nas camadas geológicas da experiência que foram obradas por estas coisas"4 (a ruptura de Auschwitz). Houve diferenças consideráveis - Adorno repudiava o existencialismo de cunho francês, ao qual Améry aderiu, e este criticou o "jargão dialético" [Jargon der Dialektik] do filósofo -, mas os dois mantiveram certo respeito mútuo à distância (HEIDELBERGER-LEONARD, 2004, p. 215). ${ }^{5}$

Na verdade, muitos grandes testemunhos são perpassados por elementos reflexivos que os aproximam do gênero ensaístico. Na obra de Primo Levi, o primeiro livro, ainda que siga uma cronologia narrativa, está centralizado na questão do título - “É isto um homem?" - eéorganizado em capítulos temáticos, ao passo que o último, Os afogados e os sobreviventes, é uma coletânea de ensaios, sendo o sexto deles dedicado a Améry. Robert Antelme, Jorge Semprun e Ruth Klüger contam suas histórias

\footnotetext{
3 “[...] macht überall die Grenzen des identifizierenden Denkens deutlich - ohne es darum doch einfach zu verwerfen."

4 "[...] die Veränderungen in den Gesteinsschichten der Erfahrung, die durch diese Dinge bewirkt worden sind, in einer geradezu bewundernswerten Weise zum Ausdruck bringt." ${ }^{5}$ A biógrafa Heidelberger-Leonard cita o título de um ensaio de Améry, de 1967, no qual ele critica um discurso filosófico que dissolve, entre outras coisas, a diferença entre perpetradores e vítimas.
} 
de sobrevivência nos campos, em certos momentos intercalando suas reflexões sobre o funcionamento da SS, dos campos e dos outros cativos. Mas nenhum dos textos empresta do ensaio sua estrutura fundamental, como acontece em Améry.

\section{JEAN AMÉRY / HANS MAYER}

O autor nasceu em 1912, como Hans Mayer, na Áustria provinciana e cresceu em ambientes pequeno-burgueses e católicos. Criado numa família assimilada, foi forçado reconhecer sua identidade judaica por causa da perseguição nazista. Ele saiu do colégio antes do exame final e nunca frequentou uma universidade, como escreveu Levi (1990, p. 129; cf. HEIDELBERGER-LEONARD, 2004, p. 96). Nos anos 1930, o autodidata trabalhou como livreiro, aproximou-se do grupo neopositivista do Círculo de Viena e fez suas primeiras tentativas literárias, escrevendo um romance (não publicado na época) e editando uma revista cultural junto a um amigo. Após a invasão da Áustria pelas tropas nazistas, Améry foge para a Bélgica com sua esposa. Em 1943, é flagrado distribuindo panfletos e levado então para o forte Breendonk, onde a SS o submete a tortura. Deportado para Auschwitz-Monowitz, sobrevive até a evacuação do campo diante da chegada do exército vermelho, passando ainda por mais três campos antes de ser libertado pelos britânicos em Bergen-Belsen. Nesse meio tempo, a jovem esposa Maria falece por uma doença cardíaca, pouco depois da prisão do marido. Améry toma conhecimento do fato somente após sua libertação.

No pós-guerra, decide voltar para Bruxelas, numa continuação do exílio, uma vez que sua "terra” austríaca já não podia ser recuperada após todos os horrores vividos. Escreve, até 1964, artigos em alemão para diários suíços, usando o pseudônimo Jean Améry, anagrama afrancesado de Mayer, conseguindo eventualmente reunir esses trabalhos em livros temáticos. No início da década de 1960, o tribunal contra Eichmann em Israel e o processo contra os guardas de Auschwitz em Frankfurt haviam criado, na Alemanha, um público mais receptivo para o tema do holocausto, e Améry oferece, à redação cultural de um programa de rádio alemão, uma espécie de ensaio sobre o intelectual no campo de concentração. Helmut Heißenbüttel, poeta experimental e redator, aceita esse primeiro ensaio, "Nos limites do intelecto" [An de Grenzen des Geistes], que é então transmitido na rádio e publicado em várias revistas. Seguem- 
-se mais quatro ensaios de 30 páginas sobre "A tortura" [Die Tortur], a questão da "terra", "O ressentimento" [Ressentiments] e "A coação para e a impossibilidade de ser judeu” [Über Zwang und Unmöglichkeit, Jude zu sein], editados juntos em 1966 no livro Jenseits von Schuld und Sühne. Bewältigungsversuche eines Überwältigten [Além de culpa e castigo. Tentativas de recuperação de um derrotado]. ${ }^{6} \mathrm{O}$ "brilho do estilo e as audácias do pensamento”, para Starobinski (2011, p. 15), características de um bom ensaio, são indiscutíveis, e a mensagem, dirigida aos alemães naquele momento, causa um impacto difícil de sobre-estimar.

A partir desse momento, Améry torna-se um intelectual de referência na República Federal da Alemanha. Entre 1965 e 1978, o Merkur, no pós-guerra a revista mais prestigiosa e exigente da Alemanha, imprime mais sessenta ensaios seus, e o autor lança livros sobre diversos assuntos: Flaubert, a idade, o suicídio e sua própria vida. Em 1974 publica o "romance-ensaio" [Romanessay] Lefeu oder der Abbruch [Lefeu ou a demolição], que não alcança o sucesso almejado. No mesmo ano tenta suicidar-se pela primeira vez, vindo a falecer quatro anos depois, num hotel em Salzburgo, em decorrência de uma overdose de soníferos.

Iniciou-se em 2002 uma edição das suas obras em nove volumes sob a coordenação de Irene Heidelberger-Leonard, crítica que também lhe dedicou uma biografia (2004). Na literatura memorialista sobre o holocausto escrita em alemão, Améry é, ao lado de Ruth Klüger, a voz mais importante, com uma bibliografia crítica cada vez mais extensa. ${ }^{7}$

\section{A GÊNESE DO TESTEMUNHO}

Lançando um olhar à gênese do testemunho de Améry, são notáveis tanto sua demora quanto a oscilação inicial entre diferentes modos discursivos. É verdade que muitos sobreviventes não sentiram a necessidade de pronunciar-se sobre os horrores vivenciados

\footnotetext{
${ }^{6} \mathrm{O}$ subtítulo alemão apresenta uma figura etymologica com a raiz "Gewalt", que significa "violência” ou "poder". A expressão "Bewältigung” era, na época, um chavão que conotava, muitas vezes, o desejo de colocar um ponto final na judicialização e na memória do holocausto. Mais tarde, o autor arrepende-se por seu uso da palavra, alegando que ele fora "superado pelo jargão" [der Bewältiger ließ sich von Jargon überwältigen] (apud SCHEIT, 2002, p. 700).

${ }^{7}$ No Brasil, por informação da plataforma Lattes, constatamos que existem somente dois trabalhos acadêmicos (Mestrado e Trabalho de Especialização) de Dirson Fontes da Silva Sobrinho, orientados por Monica Grin Monteiro de Barros, na área da História Social.
} 
imediatamente após a libertação e que na primeira década do pósguerra não houve uma atmosfera pública muito aberta para relatos sobre a perseguição na Alemanha. No entanto, segundo os documentos preservados no Deutsches Literaturarchiv Marbach, o Hans Mayer de 33 anos tinha um grande desejo de tornar-se escritor. Ainda em junho de 1945, já de volta a Bruxelas, conclui um texto datilografado de 33 páginas, intitulado "Zur Psychologie des deutschen Volkes" [Sobre a psicologia do povo alemão] - publicado no anexo de Jenseits von Schuld und Sühne. Bewältigungsversuche eines Überwältigten (AMÉRY, 2002, pp. 505-534) -, no qual discorre sobre a responsabilidade dos alemães, diferenciados em "povo", elites nazistas e elite cultural. Na tentativa de analisar as condições que possibilitaram o genocídio, ele identifica: o enrijecimento moral das gerações desde Nietzsche, a propaganda e a dedicação obstinada e absurda ao trabalho como valor em si. O texto respira uma notável verve do recém-libertado que se considera autorizado a pronunciar julgamento sobre seus perseguidores, legitimado por sua experiência e pela lógica dos argumentos, tudo na forma verbal do plural majestático. $\mathrm{Na}$ argumentação, encontram-se alguns exemplos do comportamento nazista que, conforme tudo indica, foram observados por ele mesmo. Um desses exemplos - a brutalidade fria, gratuita e cínica de um oficial da SS contra uma mulher já perturbada e uma criança - deve evidenciar a indiferença desumana da SS que, uma vez incorporada na psique pelo treinamento, jamais pode ser desaprendida. Outro exemplo mostra a forma como seu superior civil na administração da fábrica Buna, o qual era "ariano", colocou a necessidade do trabalho, mesmo despojado de qualquer sentido, sobre qualquer outro valor. Somente nesses trechos breves, que exercem sua função dentro da construção do argumento, aparecem as vivências de Améry no campo de concentração. A estrutura geral do texto mantém a máxima objetividade.

Na mesma fase biográfica, provavelmente ainda no ano de 1945, o autor começa a escrever vários textos ficcionais, entre eles um romance fragmentário cujo protagonista éum tal Egon Althager, o alter ego de Améry do seu primeiro romance juvenil, Die Schiffbrüchigen [Os náufragos], publicado postumamente em 2007. O tema daquele romance, com o qual Améry teve a intenção de, finalmente, comprovar-se como autor literário, é um amor infeliz, a memória e a morte; o projeto foi inspirado em Marcel Proust e Thomas Mann, mas não chegou a consolidar-se e permaneceu inédito. Num dos capítulos finalizados, porém, narra-se o episódio decomo 
esse Althager foi torturado numa fortaleza fictícia (Festung Derloven) na Bélgica. Muitos detalhes dessa narrativa coincidem com aquilo que Améry relatará, em 1965, no ensaio sobre a tortura que ele mesmo sofreu no famigerado forte Breendonk. No romance planejado, a presença desse tema limita-se à intenção de afirmar que o sofrimento do amor é muito maior do que o sofrimento da tortura. Aqui, Améry aparentemente considera a ruptura civilizatória nazista como um momento periférico e procura, no amor, um assunto universalmente humano que fosse digno de ser dilacerado na forma da narrativa ficcional. Suas declarações em cartas daquela época falam de um novo estado existencial após Auschwitz, que seria inscrito no personagem de Althager, mas sem ficar no primeiro plano.

Pode-se deduzir, então, que o autor, de volta à liberdade, descartara a relevância da sua própria experiência como sobrevivente, porque ela, segundo seu critério, era demasiadamente subjetiva e podia ser utilizada apenas como exemplum numa discussão teórica (no texto sobre a Psicologia do povo alemão). Na ficção, é atribuída a um personagem fictício e, novamente, não parecia ser relevante o suficiente para estabelecer um conteúdo em si mesma. Foi somente a conjuntura dos anos 1960 - a tradução alemã do testemunho de Primo Levi é publicada em 1961 - que adiantou a propensão de falar sobre sua vida no campo de concentração, mas agora num texto que inter-relaciona, com maestria, o subjetivo e o objetivo. Depois dos grandes êxitos obtidos como ensaísta, Améry achava o momento oportuno para experimentar, novamente, seu talento como ficcionalista. O "romance-ensaio" Lefeu oder der Abbruch tem como protagonista, novamente, um sobrevivente com alguns traços autobiográficos e retoma seus temas centrais - o amor, a morte e a solidão - dentro de um enredo ficcional, sem receber a ressonância esperada. Embora o romance venha atraindo a atenção de alguns críticos recentemente, pode-se supor que Améry permanecerá no cânone da literatura alemã e do testemunho da Shoah como autor dos ensaios de Jenseits von Schuld und Sühne.

\section{O ENSAIO SOBRE A TORTURA}

Os cinco ensaios do livro tratam de aspectos bem diferentes do mundo da Shoah, mas cada um deles é escrito a partir de uma perspectiva muito pessoal. "Nos limites do intelecto" é um discurso sobre a inutilidade 
da bagagem cultural que costuma ser uma vantagem na maioria das circunstâncias. Onde o ser humano é submetido à transformação em carne e em matéria inorgânica, a capacidade de interpretar ações humanas e estruturas sociais produz sobretudo desespero, e os versos de Hölderlin perdem a força de "transcender a realidade" [Das Gedicht transzendierte die Wirklichkeit nicht mehr] (AMÉRY, 2002, p. 32). ${ }^{8}$ No capítulo dedicado a Améry em Os afogados e os sobreviventes, Primo Levi expressa sua discordância do conceito "intelectual" de Améry, sentindo-se excluído enquanto homem das ciências exatas. Ainda assim, ele concorda com o diagnóstico de Améry na maioria dos casos, embora suas lembranças culturais, durante seu cativeiro, não lhe causassem repulsa. Ao contrário, para o italiano, era uma experiência importante recitar estâncias de Dante para um camarada e, dessa forma, resgatar algo da sua identidade anterior e o mundo fora do campo. Isso não podia acontecer com Améry, que se sentia desapropriado da sua cultura alemã por seus próprios algozes. O capítulo “Wieviel Heimat braucht der Mensch?” [De quanta terra precisa o homem?] remete a um título de Tolstói, com um conceito muito caro à mentalidade alemã, tematizando a situação muito especial dos judeus alemães e austríacos no holocausto. $\mathrm{O}$ autor, criado em ambientes bastante rurais e "folclóricos", sofreu com o exílio forçado do seu dialeto e do contexto da sua socialização durante toda a sua vida. O quarto capítulo, sobre os "Ressentiments" [Ressentimentos], é o que causou mais dissensão entre seus leitores, particularmente alemães que, naquela época, achavam, em grande medida, que as reparações pagas para o estado de Israel teriam resolvido o problema. É onde o autor se recusa decididamente a perdoar o que aconteceu, porque isso seria um ato imoral diante da história. O ressentimento das vítimas, considera Améry, deveria atuar como um espinho que estimulasse, a cada vez e repetidamente, no povo dos perpetradores, a desconfiança contra si mesmo, encontrando-se, no final, com o povo das vítimas no "desejo de reverter a história", o desejo de que Hitler não tivesse existido (p. 143; cf. SEBALD, 2006, pp. 161-162). O último ensaio, "Über Zwang und Unmöglichkeit, Jude zu sein" [Sobre a obrigação e impossibilidade de ser judeu], fala da identidade judaica que

\footnotetext{
${ }^{8} \mathrm{~A}$ partir daqui, as citações do livro serão feitas apenas com o número de página. Optou-se por usar nossa tradução em vez da publicada por Marijane Lisboa (AMÉRY, 2013). Esta é, com certeza, mais elegante e legível. O presente artigo, porém, está baseado no original alemão e, por isso, é melhor referir-se a este em traduções menos fluidas, mas um pouco mais literais. Para apresentar o testemunho de Améry ao público brasileiro, a tradução do livro é excelente.
} 
lhe foi imposta pelo nazismo e que ele teve que aceitar contra sua vontade. Se o "ser judeu" significa "uma propriedade cultural ou uma inerência religiosa” [einen kulturellen Besitz, eine religiöse Verbundenheit], ele nunca havia sido e nunca poderia se tornar judeu (AMÉRY, 2002, p. 151). O que o torna judeu é a exclusão e o destino de ter sido perseguido como judeu. Nessa identidade, ele não está unido com o povo judeu, mas com alguns sobreviventes isolados.

Sem confiança básica no mundo [Weltvertrauen], estou como judeu contra meu ambiente, estranho e sozinho, e tudo que posso fazer é me arranjar na estranheza. Tenho que aceitar o ser-estranho como elemento essencial da minha personalidade, permanecer nele como numa posse inalienável (p. 169). ${ }^{9}$

Elias Canetti (apud HEIDELBERGER-LEONARD, 2004, p. 236), em uma carta ao autor, de 16 de agosto de 1966, observa que esta seria a condição do "homem em si, como deveria ser hoje: rememorando a catástrofe passada, consciente da catástrofe vindoura, desprendido de todas as certezas e consolações traiçoeiras, sentindo a catástrofe em carne e osso, profeta a partir da sua própria corporeidade". ${ }^{\circ}$

Analisando no que segue em maior detalhe o ensaio sobre "A tortura", vale lembrar que este é um tema do ensaísmo desde o texto inaugural do gênero. Montaigne trata do assunto em dois capítulos do segundo volume. Em "Da consciência" (MONTAIGNE, 2000-2001, vol. II, cap. 5), ele descarta a possibilidade de descobrir a verdade mediante o interrogatório sob tortura, e, em "Da crueldade" (vol. II, cap. 11), considera a violência em castigos e execuções como algo dispensável para a justiça. Montaigne, por outro lado, não conhecia ainda a violência executada por representantes do Estado em sua forma gratuita. E seus textos baseiam-se na experiência subjetiva, pelo fato de ter observado execuções e de ter lido livros historiográficos. Ele não dispunha da experiência subjetiva da vítima, como a que está no enfoque de Améry.

\footnotetext{
9 "Ohne Weltvertrauen stehe ich als Jude fremd und allein gegen meine Umgebung, und was ich tun kann, ist nur die Einrichtung in der Fremdheit. Ich muß das Fremdsein als ein Wesenselement meiner Persönlichkeit auf mich nehmen, auf ihm beharren wie auf einem unveräußerlichen Besitz."

10 "[...] der Mensch schlechthin ist, wie er heute sein müßte: in Erinnerung an die vergangene der drohenden Katastrophe bewußt, losgelöst von allen trügerischen Sicherheiten und Tröstungen, die Katstrophe in Haut und Knochen fühlend, Prophet aus seiner eigenen Leiblichkeit heraus.”
} 
O ensaio "A tortura" é o segundo do livro e se dispõe a analisar a estrutura híbrida entre ensaio e testemunho. O crítico Sven Kramer (2004, p. 449) supõe que esse é, hoje em dia, “o texto alemão mais citado sobre a tortura" [Sein Essay Die Tortur ist heute vermutlich der meistzitierte deutschsprachige Text über die Folter]. Esse ensaio é, ao mesmo tempo, o texto mais comentado e influente de Améry; um exemplo de sua recepção produtiva é Austerlitz, o último livro de W. G. Sebald, que pode ser considerado um testemunho de segunda mão, no qual o forte Breendonk é um espaço significante ao qual o narrador volta duas vezes.

Para desenvolver a análise, se faz necessário citar trechos maiores do ensaio de Améry, não apenas para facilitar o acesso aos pontos mais relevantes ao leitor brasileiro, mas também por simples respeito à escrita de Améry. Sendo assim, faz-se necessário, a partir deste ponto, que o presente artigo se valha de citações e paráfrases extensas.

Quem visita a Bélgica como turista pode chegar por uma rota acidental ao forte Breendonk, situado a meio caminho entre Bruxelas e Antuérpia. A construção é uma fortaleza da $1^{\underline{a}}$ Guerra e, quanto às peripécias que lhe eram destinadas naquele tempo, não tenho conhecimento. Na $2^{\underline{\underline{a}}}$ Guerra, durante os breves 18 dias de resistência do exército belga em maio de 1940, Breendonk foi o último quartel-general do Rei Leopoldo. Depois, sob a ocupação alemã, se converteu numa espécie de pequeno campo de concentração, um "Auffanglager" [campo de captação] como se falava na gíria do Terceiro Reich. Hoje em dia é museu nacional da Bélgica (p. 55). ${ }^{11}$

O parágrafo inicial oferece um resumo lacônico do local Breendonk, a partir do presente da escrita, vinte anos após o acontecimento biográfico, para qualquer visitante da fortaleza. Os fatos objetivos, como em um verbete enciclopédico, contrastam com o tom coloquial que surge na confissão do desconhecimento e na expressão "gíria do Terceiro Reich”, no original "Rotwelsch", o socioleto antigo dos mendigos, vagantes e gatunos, usado aqui de forma irônica em relação à linguagem da administração nazista.

\footnotetext{
"1 "Wer als Tourist Belgien besucht, den mag vielleicht ein Zufallsweg nach dem halbwegs zwischen Brüssel und Antwerpen gelegenen Fort Breendonk führen. Die Anlage ist eine Festung aus dem ersten Weltkrieg, und welches Schicksal ihr damals beschieden war, weiß ich nicht. Im zweiten Weltkrieg, während der kurzen achtzehn Tage des Widerstandes der belgischen Armee im Mai 1940, war Breendonk eine Art von kleinem Konzentrationslager, ein "Auffanglager", wie es im Rotwelsch des Dritten Reiches hieß. Heute ist es ein belgisches Nationalmuseum."
} 
O texto continua com a aparência externa que, no primeiro momento, remete ao século XIX e a gravuras antigas, impressão que é sobreposta, com a aproximação ao lugar, por elementos mais sinistros, como atalaias, arame farpado e avisos em alemão com os dizeres "Quem avançar leva tiro" [Wer weitergeht, wird erschossen], tudo conservado fielmente pela administração do museu belga, a realidade do presente. O relato daquilo que aconteceu em 1942 parte da realidade atual do local, que guarda, na sua função de museu, os traços do passado, ou seja: o passado penetra o presente na realidade topográfica da mesma maneira como penetra o presente na mente do sujeito que foi torturado. ${ }^{12}$ Nota-se também como o texto cria uma fusão entre um passado real ( $1^{\underline{a}}$ e $2^{\underline{a}}$ Guerras), um passado imaginário (Guerra Alemanha/França de 1870) e o presente real, um efeito de desrealização e lugubridade que pode ser reencontrado, décadas depois, nas obras de Sebald.

Chegando ao edifício, nesse movimento virtual, o enfoque do narrador muda do presente para o passado, entrando numa sala que

[...] misteriosamente foi chamada de "sala de negócios". Uma imagem de Heinrich Himmler na parede, uma bandeira suástica servindo de toalha na comprida mesa, algumas cadeiras rasas. Sala de negócios. Cada um procedia ao seu negócio, e o deles era o assassinato. Depois os corredores úmidos, de porão, sob a luz tênue e avermelhada das lâmpadas penduradas lá desde aquele tempo. Celas, trancadas por portas de madeira de uma polegada. É necessário atravessar, a cada vez, de novo, pesados portais de grades, até encontrar-se numa abóbada sem janelas na qual várias ferramentas estranhas de ferro foram deixadas. De lá, nenhum grito penetrava para fora. Lá, a coisa aconteceu comigo: a tortura (p. 56). ${ }^{13}$

O leitor espera que agora se inicie o relato autobiográfico, mas esse não é o caso. Em vez disso, o autor relativiza: a tortura que ele sofreu era "comparativamente benigna" [vergleichsweise gutartig] e não deixou

${ }^{12}$ Cf. Kramer (2004, pp. 457-458).

13 “[...] der damals mysteriöserweise 'Geschäftszimmer' hieß. Ein Bild Heinrich Himmlers an der Wand, eine Hakenkreuzfahne als Tuch über einen langen Tisch gelegt, ein paar kahle Stühle. Geschäftszimmer. Jeder ging an sein Geschäft, und ihres war der Mord. Dann die feuchten, kellerigen Korridore, schwach erhellt von den gleichen dünn und rötlich leuchtenden Glühbirnen, wie sie damals schon dort hingen. Gefängniszellen, von zolldicken Holztüren verschlossen. Schwere Gittertore sind immer wieder zu durchschreiten, bis man sich schließlich in einem fensterlosen Gewölbe befindet, in dem mancherlei befremdliches Eisenwerkzeug herumliegt. Von dort drang kein Schrei nach draußen. Dort geschah es mir: die Tortur." 
cicatrizes marcantes em seu corpo. Mesmo assim, ele se sente autorizado a fazer uma declaração mais abrangente:

Entretanto me atrevo, vinte e dois anos após isso ter acontecido, na base de uma experiência que nem ao menos sondou a dimensão completa do possível, a fazer esta alegação: A tortura é o evento mais horrível que um homem pode guardar dentro de si (p. 57). ${ }^{14}$

E continua discorrendo sobre a "normalidade" com a qual as pessoas seguem torturando no mundo atual (por exemplo, no Vietnã e na Argélia) e as maneiras como se constrói uma resistência pública contra isso em diversos estados. Por que seria lícito falar, nessas condições, exatamente da tortura do Terceiro Reich? E, em resposta à pergunta retórica, ele assevera - com base em sua experiência pessoal - estar convencido de que a tortura, para o nazismo, "não era acidente, mas sua essência" 15 (p. 59).

Essa oscilação entre fragmentos narrativos, comentários teóricos e excursos históricos marca tanto esse ensaio como o estilo geral de Améry. Como observou Irene Heidelberger-Leonard (2004, pp. 322-323), ele nunca considerou importante a "reprodução" [Abbildung] da realidade, mas sim a sua "dissolução analítica, pois apenas na sua dissolução ele pôde descobrir seus efeitos mortais". ${ }^{16}$ Pode-se questionar se a maneira de analisar a realidade nos ensaios de fato "dissolve a realidade", mas, com certeza, ela desintegra sua representação narrativa.

Somente depois de três páginas falando sobre as práticas atuais da tortura, o autor continua o relato sobre sua prisão pela Gestapo após ter distribuído panfletos que, em sua avaliação posterior, eram inúteis. Ele afirma que o fato de saber teórica e detalhadamente sobre o funcionamento da SS não constituía preparação suficiente para o choque da experiência prática. 'Aquilo que se chama, assim, 'a vida normal', pode entrar em choque com a imaginação antecipada e com essa expressão trivial. [...] Na verdade, estamos olhos nos olhos diante do acontecimento e, assim, diante da realidade, apenas em momentos raros da nossa vida" (p. 63). ${ }^{17} \mathrm{~A}$

\footnotetext{
14 "Und doch wage ich, zweiundzwanzig Jahre nachdem es geschah, auf Grund einer Erfahrung, die das ganze Maß des Möglichen keineswegs auslotete, die Behauptung: Die Tortur ist das fürchterlichste Ereignis, das ein Mensch in sich bewahren kann." 15 "kein Akzidens war, sondern seine Essenz"

16 "Analytische Auflösung der Wirklichkeit, denn nur in ihrer Auflösung kann er ihrer tödlichen Wirkung auf die Spur kommen."

${ }_{17}$ “Das, was man so das 'normale Leben' nennt, mag aufgehen in vorwegnehmender Vorstellung und trivialer Aussage. [...] In Wahrheit stehen wir dem Ereignis und damit der Wirklichkeit nur in seltenen Momenten unseres Lebens Aug' in Auge gegenüber."
} 
violação da integridade do corpo precisa ser vivenciada para saber de que se trata. O mesmo aconteceu com o jovem Améry. "Eu sabia e não sabia. [...] E de repente eu senti - o primeiro golpe."18 (p. 63).

Aqui, o texto insiste na diferença entre o conhecimento discursivo do qual todos nós dispomos em maior ou menor grau e o conhecimento físico, que é propriedade de poucos. Sylvia Weiler (2012, p. 413) e Maria Lassmann (2009, p. 96) enfatizam que os ensaios de Améry aplicam o método fenomenológico de Merleau-Ponty. O conhecimento discursivo está presente nos momentos em que o autor relata e debate questões gerais da tortura. Esse conhecimento, porém, precisa ser complementado pelo outro conhecimento, "que não é codificado de forma verbal, mas gravado no corpo, chamado por Améry de vécu [vivenciado] ou de 'evidência subjetiva"' (LASSMANN, 2009, p. 96).19 O primeiro texto sobre a tortura, de 1945 (“Fortaleza Derloven", supracitado), descreve a situação em terceira pessoa, com focalização interna, de maneira que aparecem sintomas externos junto a sensações subjetivas. No ensaio de 1964, porém, o autor alterna sistematicamente entre o discurso objetivo e a descrição interna, em primeira pessoa; a sensação subjetiva é o ponto de partida, a generalização, o complemento necessário.

Consequentemente, a menção do primeiro golpe é seguida por mais uma reflexão sobre os golpes que, segundo Améry, têm pouca relevância em interrogatórios por serem aplicados com alta frequência pela polícia também em estados democráticos. Ainda assim, para a vítima, o primeiro golpe é um momento monstruoso.

O primeiro golpe leva à consciência do recluso de que ele é desprovido - e com isso já contém em germe tudo que se segue. A tortura e a morte na cela [...] estão sendo pressentidas no primeiro golpe como possibilidades reais, e até como certezas. Pode-se bater no meu rosto com o punho, sente a vítima com espanto indistinto e deduz com certeza igualmente indistinta: será feito de mim o que se quiser. Lá fora ninguém sabe disso e não há ninguém por mim (p. 65).20

\footnotetext{
18 "Ich wußte und wußte nicht. [...] Und plötzlich fühlte ich - den ersten Schlag." 19 "Wissen von Erfahrungen, das nicht sprachlich kodiert, sondern im Leib aufgezeichnet ist und das Jean Améry das vécu oder auch die 'subjektive Evidenz' nennt."

20 "Der erste Schlag bringt dem Inhaftierten zu Bewußtsein, daß er hilflos ist - und damit enthält er alles Spätere schon im Keime. Folter und Tod in der Zelle [...] werden beim ersten Schlag als reale Möglichkeiten, ja als Gewißheiten vorgespürt. Man darf mich mit der Faust ins Gesicht schlagen, fühlt in dumpfem Staunen das Opfer und schließt in ebenso dumpfer Gewißheit: Man wird mit mir anstellen, was man will. Draußen weiß niemand davon, und keiner steht für mich ein."
} 
O que Améry descreve aqui de forma fenomenológica é o que a psicologia chama de "trauma" e que, em 1964, ainda não era um tema trilhado. A violência súbita contra a qual não há defesa é o que irrompe na consciência da pessoa e arruína uma confiança construída desde a infância. O autor chama isso de Weltvertrauen, uma confiança básica no mundo, a "certeza de que o outro, baseado em contratos sociais escritos ou não escritos, me poupa, ou dito com maior exatidão, que ele respeita minha existência física e, com isso, também metafísica" (p. 66). Améry não cita o psicanalista Erik $\mathrm{H}$. Erikson, que ele provavelmente desconhece e cujo conceito "Urvertrauen" [confiança básica] estaria próximo do fenômeno descrito. Porém ele apresenta outras autoridades, como "o antigo Kropotkin" e o etólogo alemão Konrad Lorenz, para dar respaldo ao seu conceito.

Depois dessas considerações sobre a natureza da violência sofrida em condições do nazismo, o autor continua seu relato autobiográfico com o transporte da central da Gestapo para o forte Breendonk, onde atuava a própria SS. A minudência dos processos de recepção na "sala de negócios" é comentada com sarcasmo: "Pai Himmler [da imagem] olhou com satisfação para baixo, para a toalha da bandeira e para seus homens. Podia- -se confiar neles" (p. 69). ${ }^{21}$ De novo, Améry abandona o relato e defende que a tortura foi a essência do nazismo. Ele rejeita o conceito do totalitarismo de Hanna Arendt, insistindo na diferença entre nazismo e estalinismo como fenômenos políticos. De acordo com um ditame de Thomas Mann, ele considera que o comunismo ainda manteve "uma ideia do homem" e conseguiu "desestalinizar-se", ao passo que um nazismo "des-hitlerizado" seria impensável. O diferencial do hitlerismo teria sido não somente "ter praticado o poder do anti-homem, mas tendo até mesmo o elevado a princípio" (p. 71). E, numa sequência retoricamente bem elaborada, conclui:

Os nazistas torturaram, assim como outros, porque queriam apropriar-se, mediante a tortura, de informações de relevância estatal. Além disso, contudo, eles torturaram com a boa consciência da maldade. Torturaram seus presos para fins determinados, exatamente especificados. Mas eles torturaram sobretudo porque eram torturadores. Eles se serviram da tortura. Ainda mais fervorosamente, serviam a ela (p. 71). ${ }^{22}$

\footnotetext{
${ }_{21}$ "Vater Himmler blickte zufrieden herab auf das Fahnentuch, das den rohen Holztisch bedeckte, und auf seine Leute. Es war Verlaß auf sie."

${ }_{22}$ "Die Nazis folterten, so wie andere, weil sie sich mittels der Tortur in den Besitz staatspolitisch wichtiger Informationen setzen wollten. Daneben aber folterten sie mit
} 
Apenas agora, no centro do texto, seguem as duas páginas que relatam a própria tortura. Aqui, Améry coloca o nome do tenente responsável da SS ("ele se chamava Praust - P-R-A-U-S-T" [hieß Praust - P-R-A-U$\mathrm{S}-\mathrm{T}]$ ), alegando que este poderia, no exato momento da redação do relato, "estar voltando de um passeio de carro dominical, sentindo-se bem na sua pele saudavelmente avermelhada" (p. 72). Aqui, o autor fala dos detalhes circunstanciais, de como esse tenente fala para sua vítima "em voz ronquenha e aconchegante: 'É agora'”23 (p. 72). Mas aqui também ele insere a descrição quase sóbria da fenomenologia do tipo de tortura ao qual foi submetido, o chamado pêndulo.

Da abóbada do bunker pendia uma corrente sobre uma roda que carregava um pesado guincho de ferro em sua extremidade inferior. Levaram-me para este aparelho. O guincho foi colocado na algema que mantinha minhas mãos unidas nas minhas costas. Depois, a corrente foi içada comigo até eu ficar pendurado cerca de um metro do chão. É possível se manter numa posição assim, meio inclinado, com as mãos atadas nas costas, por pouco tempo com uso da força muscular. Não se responderá a perguntas, durante estes minutos escassos, esgotando-se no esforço extremo, quando o suor já está na fronte e nos lábios e a respiração está ofegante. Cúmplices? Endereços? Lugares de encontro? Isso apenas se ouve. A vida, concentrada numa única parte do corpo, estreitamente constrita - a saber, as articulações escapulares -, a vida recolhida não reage porque se esgota completamente no esforço. Mas isso não pode durar muito, mesmo em pessoas com boa condição física. No que diz respeito a mim, tive que me render bastante rápido. E agora houve um estalar e lascar nas costas que não foi esquecido pelo meu corpo até hoje. As esferas escapulares pularam dos cótilos. O próprio peso corporal causou uma luxação, eu caí no vazio e fiquei pendurado pelos braços, agora desencaixados e arrancados detrás para acima da cabeça, unidos de modo retorcido. Tortura, do latim torquere, estorcer: que aula prática de etimologia! Ainda por cima resvalaram os golpes do vergalho no meu corpo e um e outro cortou diretamente a fina calça de verão que eu vestia naquele 23 de julho de 1943 (pp. 72-73). ${ }^{24}$

dem guten Gewissen der Schlechtigkeit. Sie marterten ihre Häftlinge zu bestimmten, jeweils genau spezifizierten Zwecken. Aber sie folterten vor allem deshalb, weil sie Folterknechte waren. Sie bedienten sich der Folter. Inbrünstiger aber noch dienten sie ihr."

${ }_{23}$ "Jetzt passiert's", sagte er rasselnd und gemütlich zu mir."

24 "Im Bunker hing von der Gewölbedecke eine oben in einer Rolle laufende Kette, die am unteren Ende einen starken, geschwungenen Eisenhaken trug. Man führte mich an dieses Gerät. Der Haken griff in die Fessel, die hinter meinem Rücken meine Hände zusammenhielt. Dann zog man die Kette mit mir auf, bis ich etwa einen Meter hoch über dem Boden hing. Man kann sich in solcher Stellung oder solcher Hängung an den hinterm Rücken gefesselten Händen eine sehr kurze Weile mit Muskelkraft in der Halbschräge halten. Man wird, während dieser wenigen Minuten, wenn man bereits die äußerste Kraft verausgabt, wenn schon der Schweiß auf Stirn und Lippen steht und der Atem keucht, keine Fragen beantworten. Komplizen? Adressen? Treffpunkte? Das vernimmt man kaum. 
É notável que a "descrição objetiva" do processo começa como se o narrador não tivesse sido o sujeito que o sofreu. As frases poderiam figurar numa descrição geral do pêndulo, e mesmo aquelas que contêm o "eu" carecem de uma perspectiva interna. Não há nenhuma menção às dores, sensações ou ao desespero. O pontual registro externo é suficiente para provocar um horror no leitor. O "eu" entra na cena quando ele é forçado a sucumbir, e esse momento é o que fica gravado na memória do corpo de maneira indelével.

No parágrafo seguinte, constata a impossibilidade de transmitir a qualidade da dor com meios verbais, mediante comparações: "A dor era aquele que era" (p. 74). A alusão às palavras de Deus no Horebe, "Eu sou aquele que sou" (Êxodo 3,14) enfatiza a transcendência e indescritibilidade de qualidades sensoriais em geral (que, na realidade, podem ser verbalizadas de forma aproximada com os recursos da linguagem) e dessa dor em particular: "Quem quisesse transmitir sua dor física precisaria infligi-la e teria que tornar-se torturador ele mesmo" (p. 74).25 No entanto, se ele não consegue falar do como da dor, pode sim dizer o que ela era.

"Sua carne realiza-se totalmente na negação de si mesmo. [...] Somente na tortura, a encarnação ["Verfleischlichung”, tornar-se carne] do homem torna-se completa: uivando de dor, o torturado [...] é apenas corpo e nada além disso." (p. 74). ${ }^{26}$

E o diagnóstico final, muito citado, é: “Quem foi torturado permanece torturado. Indelevelmente a tortura fica gravada nele, mesmo que não se possa detectar traços clinicamente objetivos" (p. 75). ${ }^{27}$

Das in einem einzigen, engbegrenzten Körperbereich, nämlich in den Schultergelenken, gesammelte Leben reagiert nicht, denn es erschöpft sich ganz und gar im Kraftaufwand. Nur kann dieser auch bei physisch kräftig konstituierten Leuten nicht lange währen. Was mich betrifft, so mußte ich ziemlich schnell aufgeben. Und nun gab es ein von meinem Körper zu dieser Stunde nicht vergessenes Krachen und Splittern in den Schultern. Die Kugeln sprangen aus den Pfannen. Das eigene Körpergewicht bewirkte Luxation, ich fiel ins Leere und hing nun an den ausgerenkten, von hinten hochgerissenen Armen. Tortur, vom lateinischen torquere, verrenken: Welch ein etymologischer Anschauungsunterricht! Dazu prasselten die Hiebe mit dem Ochsenziemer auf meinen Körper, und mancher von ihnen schnitt glatt die dünne Sommerhose durch, die ich an diesem 23. Juli trug."

25 "Wer seinen Körperschmerz mit-teilen wollte, wäre darauf gestellt, ihn zuzufügen und damit selbst zum Folterknecht zu werden."

26 "Sein Fleisch realisiert sich total in der Selbstnegation. [...] Aber nur in der Tortur wird die Verfleischlichung des Menschen vollständig: Aufheulend vor Schmerz ist der gewalthinfällige, auf keine Hilfe hoffende, zu keiner Notwehr befähigte Gefolterte nur noch Körper und sonst nichts mehr."

${ }_{27}$ "Wer gefoltert wurde, bleibt gefoltert. Unauslöschlich ist die Folter eingebrannt, auch dann, wenn keine klinisch objektiven Spuren nachzuweisen sind." 
Além do efeito traumático, pode-se constatar que Améry apresenta uma descrição fenomenológica da "vida nua" de Giorgio Agamben (2010). Mas há uma diferença interessante que foi observada por Sven Kramer (2004, p. 467): "ele sofre a submissão do corpo - diferentemente dos muçulmanos - não em Auschwitz, mas sob a tortura. [...] Para ele, a tortura, não Auschwitz, converte-se em parâmetro da carnificação máxima”. ${ }^{28}$ Podemos lembrar aqui que Améry quer provar a tese de que a tortura seria a essência do nazismo. Ainda que a situação descrita se encaixe num interrogatório e se dirija contra ele na função de combatente da resistência - não contra o judeu -, sua experiência compreende este objetivo da violência nazista: aniquilar o sujeito, convertê-lo em carne. Se a qualidade das dores é indescritível, essa conclusão pode ser formulada nitidamente a partir daquilo que esse sujeito observa em si mesmo. E, embora a aniquilação continue atuando nele, o fato de ter chegado a esse diagnóstico pode ser considerado certo resgate de um novo "eu", um "eu torturado".

Vinte anos depois dos acontecimentos, Améry tem a distância necessária para analisar não somente a situação da vítima, mas também a dos perpetradores. Segundo ele, a maldade destes não era nem sádica (no sentido sexual) nem "banal". Eles eram "ignorantes burocratas da tortura" e, ao mesmo tempo, perfeitamente concentrados no seu fazer. Nos trabalhos sobre o sadismo, de Georges Bataille, Améry encontra respaldo teórico. É o prazer de expandir a corporeidade sobre o outro que move o torturador. Assassino e vítima se enfrentam como carne pura, mas só o primeiro tem a liberdade de continuar ou pausar; é ele que define o que acontece e que pode voltar, engrandecido, ao mundo normal (p. 77). Os torturadores não são movidos por emoções como fúria ou ódio - eles exercem uma tarefa; mas, ao mesmo tempo, estão profundamente "envolvidos" na sua atividade.

De toda a alma eles se dedicaram ao seu negócio, e isso se chamava poder, dominância sobre espírito e carne, excesso da expansão desprendida. Eu tampouco esqueci que houve momentos nos quais manifestei uma espécie de veneração ignominiosa a esta soberania torturante que eles exerceram sobre mim. Pois não é um deus ou pelo menos um semideus quem pode tornar um

28 "Die Unterwerfung des Körpers erleidet er - anders als die Muselmänner - nicht in Auschwitz, sondern unter der Tortur. [...] Die Tortur, nicht Auschwitz, wird ihm zum Maß für die maximale Verfleischlichung." 
homem assim completamente em corpo e em presa gemente da morte? (p. 78). ${ }^{29}$

Para o ensaísta, a questão da resistência individual contra a tortura permanece um milagre. O que capacitou um Jean Moulin para não revelar nenhum detalhe da resistência francesa diante da brutalidade notória de um Klaus Barbie e, em vez disso, até caricaturizar seu interrogador? O modelo do sujeito heroico que não sucumbe à tortura parece mais uma lembrança de outras épocas ${ }^{30}$ e não pode ser mantido quando se considera o processo de extermínio, no qual a dessubjetivação é radicalizada. Améry teve a sorte de não poder denunciar outros, por causa dos mecanismos de conspiração aplicados no seu grupo. Quando os oficiais da SS percebem isso, ele é levado de volta para sua cela e, mais tarde, será deportado para Auschwitz na sua qualidade de judeu, a qual, no momento do interrogatório, ainda não havia sido detectada. Améry sobrevive ainda aos campos de concentração, mas o trauma da tortura é persistente: "A coisa acabou por enquanto. A coisa ainda não está acabada. Ainda estou balançando sobre o chão, vinte e dois anos depois, nos braços desencaixados, estou ofegante e me acusando" (p. 79). $3^{11}$

A conclusão do ensaio, a compreensão que ele obtém dessa experiência, é a estranheza no mundo, o espanto permanente em relação à possibilidade de tornar-se carne e morte.

Quem sucumbiu à tortura não pode voltar a sentir-se em casa no mundo. A humilhação do aniquilamento não pode ser apagada. A confiança básica no mundo que, parcialmente, desmoronou já com o primeiro golpe e, na sua extensão inteira, na tortura, não é recuperada (p. 85).32

\footnotetext{
29 "Mit ganzer Seele waren sie bei ihrer Sache, und die hieß Macht, Herrschaft über Geist und Fleisch, Exzeß der ungehemmten Selbstexpansion. Ich habe auch nicht vergessen, daß es Momente gab, wo ich der folternden Souveränität, die sie über mich ausübten, eine Art von schmählicher Verehrung entgegenbrachte. Denn ist nicht, wer einen Menschen so ganz zum Körper und wimmernder Todesbeute machen darf, ein Gott oder zumindest ein Halbgott?"

${ }^{30}$ Cf. Kramer (2004).

${ }^{31}$ "Es war für einmal vorbei. Es ist noch immer nicht vorbei. Ich baumele noch immer, zweiundzwanzig Jahre danach, an ausgerenkten Armen über dem Boden, keuche und bezichtige mich."

32 "Wer der Folter erlag, kann nicht mehr heimisch werden in der Welt. Die Schmach der Vernichtung lässt sich nicht austilgen. Das zum Teil schon mit dem ersten Schlag, in vollem Umfang aber schließlich in der Tortur eingestürzte Weltvertrauen wird nicht wiedergewonnen."
} 
Provavelmente não seria muito ousado relacionar o suicídio do autor, 24 anos depois, às feridas relacionadas à sua condição de ter sobrevivido à tortura.

A análise da tortura, desenvolvida por Améry nesse ensaio, é corroborada, em grande parte, pelo estudo do sociólogo Wolfgang Sofsky (1997) sobre o poder absoluto que se manifesta nos campos de concentração. O que ele chama de "Exzesse der Gewalt" [excessos da violência], típicos da tortura e do funcionamento dos campos nazistas, constitui características fundamentais do poder absoluto, o poder sobre a vida do outro. $\mathrm{O}$ autor mostra como esse poder não surge, em primeiro lugar, da indoutrinação ideológica ou de emoções pessoais, mas da criação de um habitus particular. Os membros da SS e dos demais grupos envolvidos no processo de perseguição e extermínio foram sistematicamente acostumados à liberdade de fazer o que quisessem com as vítimas. Para essa casta dominante, a violência arbitrária e a matança constituíram uma opção permanente e comprovaram sua dominância. As crueldades foram executadas não sob comando, mas voluntariamente, para mostrar a pertença e a adaptação ao grupo.

O excesso ultrapassa o âmbito da violência regrada. Ele não é castigo, nem tortura, nem execução. Ele aceita castigo e tortura, quando muito, como oportunidade bem-vinda. Amiúde, porém, ele acontece sem qualquer pretexto, sem comando e sem fim. No excesso, o poder se esbalda no indefeso. Sua raiz está na situação da onipotência. No excesso, o perpetrador comprova seu triunfo sobre o outro. Mostra quão livre ele é. O excesso é violência por si só, terror em si mesmo (SOFSKY, 1997, p. 257).33

Vale acrescentar que Sofsky chegou a essas conclusões trinta anos depois de Améry e por meio de pesquisas extensas da bibliografia sobre o holocausto, que se desenvolveram durante esse período.

\section{5) O ENSAÍSMO DE “A TORTURA”}

A apresentação do tópico anterior deve ter elucidado algo da estrutura do texto sob análise e dos elementos que o qualificam como

\footnotetext{
33 “Der Exzeß sprengt den Rahmen geregelter Gewalt. Er ist keine Strafe, keine Folter, keine Hinrichtung. Er nimmt Strafe und Folter allenfalls als willkommenen Anlaß. Doch meistens geschieht er ohne jeden Anlaß, ohne Befehl und Ziel. Im Exzeß tobt sich die Macht an Wehrlosen aus. Seine Wurzel liegt in einer Situation der Allmacht. Im Exzeß beweist der Täter seinen Triumph über den anderen. Er zeigt, wie frei er ist. Der Exzeß ist Gewalt um ihrer selbst willen, Terror an sich.”
} 
ensaio. O subtítulo do livro, escolhido pelo autor, indica o gênero, uma vez que "Versuch" [tentativa] é um dos sinônimos de "ensaio" em alemão. O prefácio da segunda edição de 1976 apresenta o livro como "tentativa de refletir sobre a conditio inhumana das vítimas do Terceiro Reich" (p. 11). ${ }^{34}$ Os cinco textos seriam, então, "tentativas" de dominar aquilo que o dominou, ou seja: ensaios sobre o poder aniquilador, escritos por alguém que foi (quase) aniquilado. A obra, que surgiu assim, ele descreve como “confissão pessoal, (inter)rompida por meditações”35 (p. 21).

Evidente é que o texto não é, em primeiro plano, uma narrativa como a maioria dos relatos de sobreviventes, uma vez que esta apresenta uma sequência de eventos no tempo ou "a mudança do estatuto de objetos concretos" [change of state' of concrete objects] (AUMÜLLER 2014, p. 854). Para Sebald (2006, p. 155), Améry não podia servir-se de "narrativa em qualquer sentido tradicional", como também "abdicou de toda forma de literarização, que pudesse facilitar algo como uma cumplicidade entre o escritor e seus leitores" ${ }^{36}$ Ao oferecer seu primeiro ensaio à radioemissora alemã, Améry (apud SCHEIT, 2002, pp. 642-643) anuncia algo que não seria "nenhuma relação documental como já existem tantos, mas reflexões em forma de diário sobre problemas existenciais elementares do universo dos campos". ${ }^{37}$ Ele achava que era necessário escrever algo novo e diferente porque já havia uma boa base historiográfica sobre os fatos (por exemplo de: Eugen Kogon, Hans Günther Adler, Franz Neumann, Hanna Arendt, Raul Hilberg, além dos 23 volumes de documentação do Processo de Nuremberg) e uma série de memórias pessoais (entre outros: Primo Levi, Robert Antelme, Eli Wiesel, Hermann Langbein, Jorge Semprun, Tadeusz Borowski).

Em carta a um amigo, de fevereiro de 1964, Améry (2007a, p. 103) agradece pelo envio de alguns "livros sobre campos" [Lagerbücher] que estudara para seu artigo, mas não fica claro quais foram consultados de fato. O próprio livro Além de culpa e castigo menciona vários autores: Primo Levi, Hanna Arendt, o diário Goethe in Dachau de Nico Rost (1946) e o "livrinho Oranienburg" de Gerhart Seger (1934), que Améry conhecera

\footnotetext{
34 "Versuch, nachzudenken über die conditio inhumana der Opfer des Dritten Reiches".

35 "Eine durch Meditationen gebrochene, persönliche Konfession."

36 "Eine Erzählung in irgendeinem herkömmlichen Sinn"; "sie verzichtet darum auf jede Form von Literarisierung, die so etwas wie Komplizität zwischen dem Schreibenden und seinen Lesern befördert hätte."

37 "[...] keinen Dokumentarbericht, wie es deren ja schon viele gibt, sondern Reflexionen in Tagebuchform über fundamentale existentielle des KZ-Universums.”
} 
inclusive antes da deportação. Na redação dos seus textos, o autor podia pressupor que os leitores (e ouvintes) alemães estivessem grosso modo informados e que não seriam muito propensos a receber mais detalhes sobre as atrocidades cometidas por seus compatriotas durante a guerra. Há um trecho, no primeiro ensaio, no qual ele se refere a um "amigo benevolente" que lhe havia recomendado escrever muito pouco sobre Auschwitz e muito mais sobre a intelectualidade porque "o público estava alérgico a esse conceito geográfico, histórico e político" (AMÉRY, 2002, p. 23)..$^{38} \mathrm{O}$ autor não concorda com esse "amigo", mas o raciocínio proferido pode ser um motivo adicional para não relatar extensamente as vivências pessoais, com exceção daquelas que são imprescindíveis para sua argumentação. Quando começa o trecho sobre o pêndulo, ele praticamente pede desculpas, porque "infelizmente não pode poupar o leitor da descrição objetiva, para chegar, finalmente, à análise da tortura” (p. 72).39 Diferentemente de Primo Levi e tantas outras testemunhas, não sabemos quase nada da vida de Améry em Auschwitz, o que coloca em destaque o nível de abstração e a integração funcional de suas vivências.

Como já indica o título "A tortura”, com artigo definido, o que impele o texto não é o intuito de comunicar contingências biográficas, sejam elas as mais extremas possíveis. $\mathrm{O}$ ponto de partida é, naturalmente, a observação implacável e nítida daquilo que aconteceu de fato. Mas o enfoque está na compreensão do que é a tortura e qual seu significado dentro do universo nazista e do mundo humano. Por isso, a narração de acontecimentos e sensações está subordinada àquilo que Hegel chama de o "esforço da abstração" [Anstrengung des Begriffs], um movimento que parte da certeza sensorial para o conhecimento objetivo. Como Améry afirma, no prefácio, o ponto de partida é, de fato, a experiência vivida, e o texto documenta o caminho intelectual para a compreensão do que foi vivenciado. Isso implica tanto conhecimentos históricos e políticos sobre as práticas atuais da tortura quanto a capacidade de dedução lógica, como acontece, por exemplo, na definição e explicação do termo "confiança básica”. Na demonstração daquilo que é seu próprio objeto, no entanto, os raciocínios baseiam-se, fundamentalmente, na experiência pessoal que é intercalada nas declarações universalizantes.

\footnotetext{
${ }_{38}$ "Das Publikum sei allergisch gegen diesen geographischen, politischen, geschichtlichen Begriff."

39 "Will ich endlich zur Analyse der Tortur kommen, dann kann ich dem Leser leider die sachliche Beschreibung dessen, was sich ereignete, nicht ersparen."
} 
O processo da produção do texto, na medida em que foi comentado pelo autor, também lança uma luz sobre seu gênero ensaístico. No prefácio à primeira edição de 1966, observam-se as formulações nas quais Améry qualifica a escrita como o próprio processo de compreensão. Inicialmente, ele quis "apenas entender sobre um problema particular" (p. 20) e "somente na execução da escrita desvendou-se aquilo que havia entrevisto vagamente antes, num devaneio meditativo meio consciente, que hesita no umbral da expressão verbal" (pp. 20-21)..$^{\circ}$ Se a intenção original era escrever de forma distanciada e objetiva, ele experimenta só agora, escrevendo, que o "eu" que quis evitar era "o único ponto de partida que lhe servia" (p. 21).

Contrário a essa autoavaliação, o texto se apresenta muito mais como um discurso sobre o fenômeno geral da tortura, embora ancorado na experiência subjetiva, mas sempre voltando ao patamar da abstração. Ao que parece, quantitativamente, as expressões impessoais e coletivas ("wer", "man”, “er”, "ein Mensch”, “wir”) prevalecem sobre o "eu” confessional. O pronome da primeira pessoa singular tampouco se refere exclusivamente ao "protagonista", o sujeito do enunciado, mas muitas vezes ao sujeito da enunciação. Este pode fazer declarações seja sobre as vivências passadas, seja sobre sua interpretação atual. Nas palavras de Jan Philipp Reemtsma (2008, p. 486): "A tranquilidade e a imperturbabilidade da voz que diz 'eu' foram adquiridas por meio da distância”. ${ }^{11} \mathrm{O}$ sujeito da enunciação generaliza, muitas vezes, duas conclusões, mas, quando se trata da experiência pessoal que está na raiz das generalizações, ela fala de si mesma, da alteração contínua que a tortura provocou nesse "eu".

A experiência pessoal, principalmente, não pode ser transmitida, pelo menos não mediante uma simples descrição verbal. $O$ ensaio, contudo, pode valer-se de recursos literários. Já no segundo parágrafo, sobre a aparência visual do forte Breendonk, Améry vai além de uma descrição. $\mathrm{O}$ texto introduz uma ambiguidade entre a realidade - o forte foi construído na $1^{\text {a }}$ Guerra - e a aparência, que é "muito antiga", fazendo pensar no século XIX, como uma "gravura melancólica da guerra de 1870" [wie eine melancholische Gravüre aus dem Siebzigerkrieg] (p. 55). Evidentemente,

\footnotetext{
40 “[...] mir nur über ein Sonderproblem [...] klarwerden.”; “Erst im Vollzug der Niederschrift entschleierte sich, was ich vorher in einer halbbewußten, an der Schwelle des sprachlichen Ausdrucks zögernden Denkträumerei undeutlich erschaut hatte".

${ }_{41}$ "Die Ruhe und die Unbeirrbarkeit der Stimme, die da 'ich' sagt, ist aus der Distanz gewonnen."
} 
essa impressão é subjetiva e perspectivada. "Pensa-se em Gravelotte e Sedan [antigas batalhas entre alemães e franceses] e acredita-se que, num instante, o vencido imperador Napoleão III sairia, o quepe na mão, de um dos poderosos portais acocorados." (p. 55).42 Aproximando-se ao edifício, a imagem inócua vai sendo sobreposta por outra que "nos é mais corriqueira": sentinelas e "cercas de arame farpado tecendo uma rede" ao redor do forte (pp. 55-56). ${ }^{43}$ De novo, o que se vê, de fato, vai sendo completado por associações com as representações visuais: "a gravura de 1870 vai sendo sobreposta, subitamente, pelas fotos atrozes daquele mundo que David Rousset chamou de 'l'Univers Concentrationnaire'” (p. 56). ${ }^{44}$

No nível da argumentação, essas percepções e "fantasias" recebem um significado universal por meio do pronome impessoal ("man" e depois "wir"), como se as associações individuais de Améry pudessem ser generalizadas. Ao mesmo tempo, a cena estimula a imaginação do leitor como se fosse um texto de ficção, facilitando a imersão no mundo da diegese. Sendo essa realidade a da vítima, o leitor pode, ainda que parcialmente, mergulhar naquilo que foi a experiência do autor. Essa qualidade "sensorial" do discurso ensaístico pode ser observada de forma intensificada no trecho supracitado sobre a entrada no forte Breendonk. Mas ela se estende até chegar a frases que não tratam da experiência do autor, a uma frase, por exemplo, que deve dizer apenas: "minha tortura não era particularmente brutal" [war bei weitem nicht die schlimmste Form der Folter]. Para fazer isso, Améry se vale de exemplos concretos que funcionam quase como o "efeito do real": "Não me empurraram agulhas ardentes sob as unhas dos dedos e ninguém apagou um charuto aceso no meu peito nu" (pp. 56-57).45

Esses artifícios são técnicas conhecidas da retórica. De acordo com a teoria, o efeito persuasivo do discurso é ampliado quando se usam figuras que ocupam a imaginação do público e geram evidentia. O leitor pode aproximar-se melhor dos raciocínios de Améry quando este incorpora

\footnotetext{
${ }_{42}$ "Man denkt an Gravelotte und Sedan und glaubt, es müsse in einem der mächtigen geduckten Tore der geschlagene Kaiser Napoleon III. mit dem Képi in der Hand erscheinen.” 43 "[...] das uns geläufiger ist: Wachtürme erheben sich längs des Grabens um die Festung. Stacheldrahtzäune umspinnen sie."

44 "Der Kupferstich von 1870 wird jählings überlagert von den Greuelfotos aus jener Welt, die David Rousset 'l'Univers Concentracionaire' genannt hat."

45 "Mir hat man keine glühenden Nadeln unter die Fingernägel getrieben, noch hat man auf meiner nackten Brust Zigarren ausgedrückt."
} 
elementos que não pertencem exclusivamente à experiência da vítima torturada, mas também à de todos nós. Isso pode ser também uma cena quase fílmica, como a seguinte:

Tenho alguns motivos que justificam a hipótese de que os soldados em verde militar, que encontraram nossos escritos multiplicados na frente dos seus quartéis, os encaminharam, ato contínuo e batendo os tacões, para seus superiores que, por sua vez, informaram, com a mesma prontidão regimentar, os serviços de segurança (p. 6o)..$^{46}$

Em outros momentos, a descrição sensorial da realidade é feita mediante a figura da preterição (paralipse): "Seria tentador tomar alento, neste momento, e contar da viagem de carro Bruxelas-Breendonk em 25 quilômetros de terra flamenga, dos álamos inclinados pelo vento, que se viam com alegria, embora as algemas doessem nos pulsos" (p. 68). ${ }^{47}$ No início da narrativa "Fortaleza Derloven", de 1945, lê-se essa descrição da paisagem de forma extensa, numa página inteira (AMÉRY, 2007a, p. 583). Mas, mesmo nessa forma abreviada, ela exerce sua função: criar no leitor a sensação de assistir aos acontecimentos, propiciar que ele se aproxime da situação vivencial do protagonista para poder partilhar uma experiência impartilhável.

Na própria cena da tortura, é a descrição do tenente que colabora com a imersão do leitor. O homem, ao qual os outros se dirigem como "Seu tenente", é

[...] baixo, de figura entroncada e tinha este rosto carnoso, sanguíneo, que, provavelmente, seria chamado, na fisiognomia banal, de 'rabugentobenevolente'. Sua voz rouca chacoalhava, o tom era dialetal, berlinense. No pulso pendurava, numa alça de couro, um vergalho de, talvez, um metro de comprimento (p. 72)..48

\footnotetext{
46 "Ich habe manchen Grund zur Annahme, daß die feldgrauen Soldaten, die unsere vervielfältigten Schriften vor ihren Kasernen fanden, sie stracks und hackenklappend ihren Vorgesetzten weitergaben, die ihrerseits dann mit der dienstlichen Fixigkeit die Sicherheitsbehörden verständigten."

47 "Verlockend wäre es, hier Atem zu holen und von der Autofahrt Brüssel-Breendonk über fünfundzwanzig Kilometer flandrischen Landes zu erzählen, von den windgebeugten Pappeln, die man mit Freude sah, auch wenn an den Handgelenken die Fessel wehtat."

48 "Er war klein, von gedrungener Gestalt und hatte jenes fleischige, sanguinische Gesicht, das man wohl in der Banalphysiognomik 'bärbeißig-gutmütig' nennen würde. Seine Stimme rasselte heiser, der Tonfall war berlinisch dialekthaft. Am Handgelenk hing ihm in einer Lederschleife der Ochsenziemer von der Länge vielleicht eines Meters.”
} 
O tom da voz do torturador, inclusive, já evoca a corrente do aparelho da tortura, sendo o verbo chacoalhar [rasseln] a expressão onomatopaica usada para o movimento dos elos [Kette] na sua roda: o homem se assemelha ao seu instrumento, homem e máquina se aproximam na visão retrospectiva da vítima. Com a enunciação do nome civil "P-R-A-U-S-T" (p. 72), cria-se, inclusive, uma referência direta à realidade extratextual, e a procuradoria alemã poderia ter usado o testemunho para iniciar uma investigação, algo que não aconteceu, pelo que se sabe.

Por meio dos elementos analisados, o texto adquire qualidades literárias que são a essência do ensaio. É verdade que eles são pontuais e não dominam o texto, mas o permeiam em todas as partes e facilitam a participação empática do leitor. O laconismo do estilo não é um impedimento para a aproximação. Ao contrário: o leitor tem a impressão de que o autor se esforça para poupá-lo do horror extremo, e isso aumenta ainda mais sua abertura para a experiência do outro. E ainda há limites marcados pelos avisos de que a vivência na sua totalidade não pode ser verbalizada. 49

É verdade também que boa parte desses elementos é resultado de uma redação habilidosa, uma aplicação bem-sucedida da retórica. Trata-se de efeitos na imaginação do leitor, não de representações miméticas de uma realidade passada. Nada garante que o torturador tivesse exatamente essa aparência ou que Améry se lembrasse corretamente dos detalhes evocados. Mas é o autor físico que se responsabiliza por seu texto de forma autobiográfica, tanto pelas declarações objetivas quanto pelas biográficas. As deduções mais relevantes do texto resultam da experiência autobiográfica, e o leitor só pode apreendê-las quando reconhece a autenticidade da experiência. E isso é um traço particular do testemunho que vai um passo além do ensaísmo em sua forma comum.

\section{6) O TESTEMUNHO}

Michel de Montaigne abre o primeiro volume dos seus Essais dirigindo-se ao leitor e asseverando ser esse um livro "sincero". A tradução alemã de 1953 diz: "Dies hier ist ein aufrichtiges Buch" [Isto aqui é um livro sincero]. No seu primeiro prefácio, Améry (p. 22) fala de "folhas que podem ser insuficientes, mas [ele] pode insistir que elas são sinceras

${ }^{49}$ Cf. Kramer (2004). 
[aufrichtig]", ou seja, ele utiliza a mesma ênfase colocada na qualidade ética da sua escrita. O valor do texto e sua forma de recepção, portanto, estão indissociavelmente vinculados ao caráter do autor e à sua condição de ter vivenciado o extremo. Mesmo que o ensaio, de forma geral, seja um texto subjetivo, a ênfase na autoria é algo específico do testemunho.

No mesmo prefácio, Améry informa sobre o longo silêncio após a guerra e sobre como lhe foi "difícil falar do assunto"; mas, uma vez que "o encanto foi quebrado, tudo queria ser dito" (p. 20)..$^{\circ}$ De forma breve, isso evoca primeiro a impossibilidade de comunicar-se e, depois, a necessidade de dizer tudo - hoje em dia lugares-comuns da literatura testemunhal.

Outro traço típico do testemunho é a definição do público-alvo. ${ }^{51}$ Não se trata dos camaradas do campo - "eles sabem"; o autor se dirige aos "alemães que na sua maioria já não se sentem atingidos pelos atos mais lúgubres e, ao mesmo tempo, mais característicos do Terceiro Reich" (p. 22)..$^{22} \mathrm{Ou}$ seja, desempenha-se um discurso direcionado que não perde de vista seus leitores e quer transmitir a experiência tanto para aqueles que eram responsáveis - em 1964 a maioria deles ainda estava viva - quanto para os que conviviam com o nazismo sem tomar consciência da gravidade dos acontecimentos.

O "diálogo" com leitores é explicitado em vários momentos, nas perguntas retóricas ("O que me induz, na realidade, a falar da tortura exclusivamente em relação ao Terceiro Reich?”, p. 59; "Por que deveria, afinal, calar o nome dele?", p. 72) ou na figura da concessio ("Aí escuto levantar-se discordância veemente [...]", p. 70).53 O destinatário do texto é a pessoa que poderia levantar uma série de reparos, uma vez que ele pode duvidar se a instituição do campo de concentração era, de fato, tão diferente, tão específica e o efeito no sobrevivente tão irreversível assim. A intenção de Améry era, e isso pode ser extraído da estrutura do texto,

${ }_{50}$ "[...] daß es mir schwer gewesen war, davon zu sprechen"; "Nun aber, da durch die Niederschrift des Essays über Auschwitz ein dumpfer Bann gebrochen schien, wollte plötzlich alles gesagt sein."

${ }^{51}$ Cf. Assmann (2008, p. 13).

${ }_{52}$ "Den Deutschen freilich, die in ihrer überwältigenden Mehrheit sich nicht oder nicht mehr betroffen fühlen von den zugleich finstersten und kennzeichnendsten Taten des Dritten Reiches."

53 "Wie komme ich eigentlich dazu, von der Tortur gerade nur im Zusammenhang mit dem Dritten Reich zu sprechen?”; “Aber warum sollte ich eigentlich seinen Namen verschweigen?"; "Ich höre nochmals entrüsteten Widerspruch sich erheben”. 
superar essas dúvidas; o impacto que teve nos intelectuais e nas gerações desde a publicação em 1964 comprova que a estratégia foi bem-sucedida.

É certo que a autenticidade do testemunho não é simplesmente dada, sendo ele um texto que "é produzido de forma literária", como escreve Manuela Günter (2002, p. 22), para citar uma voz alemã que represente a crítica desconstrutivista. Mas, ao mesmo tempo, esse produto literário está inserido num contexto social no qual o autor se comunica sobre acontecimentos que essa mesma sociedade reconhece como fatos históricos e sobre os quais ele pode pronunciar-se por meio de sua forma particular. Ainda que ele use recursos literários e retóricos, a pessoa física que é a fonte da enunciação deve suportar o peso das suas declarações em todos os sentidos. Seria pouco adequado deixar de fora esse contexto social e limitar-se àquilo que o mero texto apresenta: ambos formam uma unidade na comunicação social. O que, nos termos de Adorno, torna-se forma literária nos textos de Améry é o Sachgehalt, o teor objetivo inerente à experiência do sobrevivente e que está profundamente inter-relacionado com aquela formação políticosocial que produzia os campos.

De acordo com Aleida Assmann (2008, p. 13), uma voz mais pragmática na teoria do testemunho e da memória coletiva, o testemunho não pode ser monológico e simplesmente memorialista porque ele "precisa do receptor" que torne o "ato performativo" de testemunhar em um ato cumprido. A autora distingue quatro tipos "ideais" (no sentido weberiano) de testemunhas: 1) a jurídica; 2) a religiosa; 3) a histórica; e 4) a moral. No contexto do holocausto, o último tipo - no qual confluem os três anteriores - é o paradigma mais reconhecível. O livro de Améry, como a maioria dos testemunhos de sobreviventes, apresenta características de cada um deles. O jurídico aparece na denunciação do nome do torturador (p. 72). O mártir - a testemunha religiosa - aparece no fato de Améry ter sobrevivido à tortura e ao campo, sendo seu próprio corpo o testemunho da violência ilícita que se manifestava no nazismo. A testemunha histórica é quem observou os acontecimentos (não necessariamente com os próprios olhos) e sabe relatá-los para aqueles que não participaram. A testemunha moral - aqui Assmann baseia-se em Avishai Margalit - é aquela que reúne traços dos outros três tipos: vítima e testemunha numa só pessoa, não por meio da morte, mas da sobrevivência. Ela é testemunha daqueles que não sobreviveram; 
ela "agoura o mal por excelência” [künden vom Bösen schlechthin] (ASSMANN, 2008, p. 19).

Em outro ensaio sobre o gênero, Assmann (2011) enfatizou o fator diferencial da experiência individual. Se a relevância da autoria para o significado de um texto literário vem sendo questionada cada vez mais, durante a segunda metade do século XX o testemunho reintroduz o autor físico como elemento crucial. A "experiência pessoal é per definitionem inalienável; não se pode transmiti-la como uma informação e incorporá-la” (ASSMANN, 2011, p. 216). ${ }^{54} \mathrm{Na}$ medida em que o testemunho depende da experiência pessoal, é o autor que se torna a instância mais relevante. Como pessoa histórica e como sujeito da escrita, ele deve construir, nos leitores, a confiança que permite que seu testemunho seja reconhecido e assimilado. Pensando no caso de Améry, temos que acrescentar que não é simplesmente sua integridade moral e sua capacidade literária, mas também seu poder intelectual que o instalam como autoridade testemunhal.

Muito antes das considerações de Assmann que resumem e apontam décadas de debates teóricos, Helmut Heißenbüttel, redator responsável pela aceitação e transmissão dos ensaios de Améry, mostrou seu entendimento sobre a importância da "autenticidade" do texto, ou seja, da sua vinculação com um autor verdadeiro. Contra as reservas de Améry, que achava que sua voz não se prestava à leitura pública e radiofônica, Heißenbüttel insistiu que ele mesmo lesse seus textos nas gravações (SCHEIT, 2002, pp. 644 ss.). Mais do que o estilo da pessoa, era a voz, a ressonância do corpo do sobrevivente, que podia transmitir sua mensagem de forma convincente.

Diferentemente de textos mais narrativos, os ensaios de Améry enfrentam seus leitores com conclusões que são resultados do seu próprio "esforço de conceito". Ele não abre mão da interpretação dos acontecimentos. A própria vítima reivindica a soberania sobre o significado do holocausto e formula seu juízo sobre os alemães que fizeram o que fizeram e continuam vivendo nas suas casas como se nada tivesse acontecido. Ele reivindica o direito da sua interpretação inclusive contra as teorias de autoridades como Theodor W. Adorno e Hanna Arendt, que recebem duras críticas nesses ensaios; para Améry, sua

\footnotetext{
54 "Eigene Erfahrung ist per definitionem unveräußerlich; man kann sie nicht wie eine Information übertragen und sich einverleiben."
} 
vivência é mais legitimadora do que a capacidade intelectual daqueles que não passaram pela tortura e pelo campo, que somente dispõem de conhecimento discursivo. É o gênero do ensaio que permite superar o testemunho narrativo e autobiográfico - o ensaio entendido como gênero indissociável da experiência pessoal, representada mediante técnicas literárias e avaliada por operações teóricas.

A forma como Jean Améry venceu essa tarefa é exemplar. O ensaísmo, desde o início, correspondeu mais ao seu talento particular do que à ficção e, em conjunção com aquilo que ele sofreu, como tantos outros, esse talento se manifestou no momento certo da história do pós-guerra. Encontrando o equilíbrio entre representação estética da experiência vivenciada e reflexão, Améry se tornou um clássico da literatura alemã, ainda que isso não tenha acontecido no campo da ficção, como era o seu anseio. No sentido de Bense (1952, p. 24), ele não é um "poeta”, que "amplia o ser num sentido ontológico, mas um escritor que trabalha constantemente no perfilamento da essência do ser"; 55 porém, assim podemos concluir, para a época em que nasceu, o segundo era pelo menos tão preciso quanto o primeiro.

\section{REFERÊNCIAS}

ADORNO, Theodor W. Metaphysik. Begriffe und Probleme. In: TIEDEMANN, Rolf (org.). Nachgelassene Schriften. Vorlesungen. Abteilung IV; v. 14. Frankfurt a.M.: Suhrkamp, 1998 [1965].

ADORNO, Theodor W. Der Essay als Form. In: TIEDEMANN, Rolf (org.). Noten zur Literatur. Gesammelte Schriften Bd. 11. Frankfurt am Main: Suhrkamp, 2003a [1958], pp. 9-33.

ADORNO, Theodor W. O ensaio como forma. In: ADORNO, Theodor W. Notas sobre literatura. Trad. Jorge de Almeida. São Paulo: Duas Cidades, 2003b, pp. 15-45.

AGAMBEN, Giorgio. O que resta de Auschwitz. O arquivo e a testemunha. São Paulo: Boitempo, 2010.

AMÉRY, Jean. At the Mind's Limits: Contemplations by a Survivor on Auschwitz and Its Realities. Bloomington: Indiana University Press, 1980.

55 “[...] daß der Dichter in einem ontologischen Sinne das Sein vermehrt, während der Schriftsteller mit jeder Tendenz beständig an der Herausarbeitung der eigentlichen Essenz jenes Seins arbeitet." 
AMÉRY, Jean. Jenseits von Schuld und Sühne. Bewältigungsversuche eines Überwältigten. In: SCHEIT, Gerhard (org.). Werke Band 2. Jenseits von Schuld und Sühne. Unmeisterliche Wanderjahre. Örtlichkeiten. Stuttgart: Klett-Cotta, 2002, pp. 7-177.

AMÉRY, Jean. Die Festung Derloven. In: HEIDELBERGER-LEONARD, Irene (org.). Werke Band 1. Die Schiffbrüchigen. Lefeu oder Der Abbruch. Stuttgart: Klett-Cotta, 2007a, pp. 582-6o8.

AMÉRY, Jean. Werke. Band 8. Ausgewählte Briefe 1945-1978. Gerhard Scheit (org.). Stuttgart: Klett-Cotta, 2007b.

AMÉRY, Jean. Além do crime e castigo. Tentativas de superação. Trad. Marijane Lisboa. Rio de Janeiro: Contraponto, 2013.

ASSMANN, Aleida. Wem gehört die Geschichte? Fakten und Fiktionen in der neueren deutschen Erinnerungsliteratur. In: Internationales Archiv für Sozialgeschichte der deutschen Literatur, v. 36, n. 1, 2011, pp. 213-225.

ASSMANN, Aleida. Vier Grundtypen von Zeugenschaft. In: PETZOLD, Ulrike (org.). Zeugen und Zeugnisse: Bildungsprojekte zur NS-Zwangsarbeit mit Jugendlichen. Berlin: Stiftung Erinnerung / Verantwortung und Zukunft, 2008, pp. 12-26.

AUMÜLLER, Matthias. Text type. $2^{\text {a }}$ ed. In: HÜHN, Peter (org.). Handbook of narratology. Berlin, New York: de Gruyter, 2014, pp. 854-867.

BENSE, Max. Plakatwelt. Vier Essays. Stuttgart: dva, 1952.

GÜNTER, Manuela. Writing Ghosts. Von den (Un-)Möglichkeiten autobiographischen Erzählens nach dem Überleben. In: GÜNTER, Manuela (org.). Überleben schreiben. Zur Autobiographik der Shoah. Würzburg: Königshausen \& Neumann, 2002, pp. 21-50.

HEIDELBERGER-LEONARD, Irene. Jean Améry. Revolte in der Resignation Biographie. Stuttgart: Klett-Cotta, 2004 .

HOWLAND, Jacob. Intellectuals at Auschwitz: Jean Améry and Primo Levi on the Mind and Its Limits. Holocaust and Genocide Studies, v. 29, n. 3, 2015, pp. 353-373.

KRAMER, Sven. Die Folter in der Literatur. Ihre Darstellung in der deutschsprachigen Erzählprosa von 1740 bis nach Auschwitz. München: Fink, 2004.

LASSMANN, Maria. Die Grenzen des Körpers, die Grenzen der Sprache. Jean Améry und Maurice Merleau-Pontys Phänomenologie. In: HEIDELBERGER-LEONARD, Irene \& LÜHE, Irmela von der (orgs.). Seiner Zeit voraus: Jean Améry-ein Klassiker der Zukunft? Göttingen: Wallstein, 2009, pp. 91-102.

LEVI, Primo. Die Untergegangenen und die Geretteten. München: Einaudi, 1990. 
LUKÁCS, Georg. Über Wesen und Form des Essay. In: LUKÁCS, Georg. Die Seele und die Formen. Essays. Berlin: Egon Fleischel, 1911[1986], pp. 1-40.

MONTAIGNE, Michel de. Os ensaios. 3 vols. Trad. Rosemary Costhek Abílio. São Paulo: Martins Fontes, 2000-2001.

OLMOS, Ana Cecilia. Ensaio de narradores na literatura latino-americana (1970-2010). Tese (Livre-docência em Letras) - Universidade de São Paulo, São Paulo, 2016.

REEMTSMA, Jan Philipp. Gedanken über den Gebrauch der ersten Person Singular bei Jean Améry. In: HEIDELBERGER-LEONARD, Irene. Améry, Jean. Werke. Band 9. Materialien. Stuttgart: Klett-Cotta, 2008, pp. 467-504.

SCHÄRF, Christian. Essay. In: LAMPING, Dieter (org.). Handbuch der literarischen Gattungen. Stuttgart: Kröner, 2009, pp. 224-233.

SCHEIT, Gerhard. Nachwort [para o livro Jenseits von Schuld und Sühne]. In: SCHEIT, Gerhard. Werke Band 2. Jenseits von Schuld und Sühne. Unmeisterliche Wanderjahre. Örtlichkeiten. Stuttgart: Klett-Cotta, 2002, pp. 629-692.

SCHLAFFER, Heinz. Essay. In: WEIMAR, Klaus. Reallexikon der deutschen Literaturwissenschaft. Berlin / New York: de Gruyter, 2007, pp. 522-525.

SEBALD, W. G. Mit den Augen des Nachtvogels. Über Jean Améry (1988). In: Campo Santo. Frankfurt am Main: Fischer, 2006, pp. 149-170.

SOFSKY, Wolfgang. Die Ordnung des Terrors. Das Konzentrationslager. Frankfurt am Main: Fischer, 1997.

STAROBINSKI, Jean. É possível definir o ensaio? Trad. Bruna Torlay. Remate de Males, v. 31, n. 2, 2011[1985], pp. 13-24.

WEILER, Sylvia. Jean Amérys Ethik der Erinnerung. Der Körper als Medium in die Welt nach Auschwitz. Göttingen: Wallstein, 2012. 